\title{
Public-private partnerships, part 1: the next hospital wave
}

A nyone who works in a hospital knows how incredibly complex the institutions are - and how important they are to Canadians when serious health problems plague them or their loved ones.

So it is surprising that a sea change in the way that many Canadian hospitals are now being developed has gone largely unheralded and unexamined by health care professionals, academics and the public.

Canada's 3 most populous provinces - Ontario, Quebec and British Columbia - have been shifting from traditional procurement methods to publicprivate partnerships (P3s) to design, build, finance, maintain and, sometimes, operate hospitals.

In Ontario alone, 19 hospitals are being financed and constructed by private sector consortia, and deals are close to completion for another 7 , says David Livingston, president of the government agency Infrastructure Ontario.

"There has never been that much activity happening all at the same time," he notes.

And in Quebec, the proposed new McGill University Health Centre, with a price tag originally estimated at $\$ 1.57$ billion, is "amongst the largest hospital redevelopment projects in the world" (Healthc Manage Forum, Winter 2007, pages 33-6).

But even as several provincial governments are encouraging this new way of financing and developing hospitals, there's been minimal public scrutiny of the new arrangements. Provincial auditor generals, the watchdogs of the public's fiscal interest, have not yet publicly reported any rigorous examination of the deals.

Some attention has been paid, though, in the Canadian financial press, where there are headlines like "Law Firms Ride P3 boom: 'every province and territory is looking at them" ( $\mathrm{Na}$ tional Post 2008 May 14); "We should face down opponents of PPPs" ( $\mathrm{Na}$ tional Post 2008 Feb 20); and "The P3

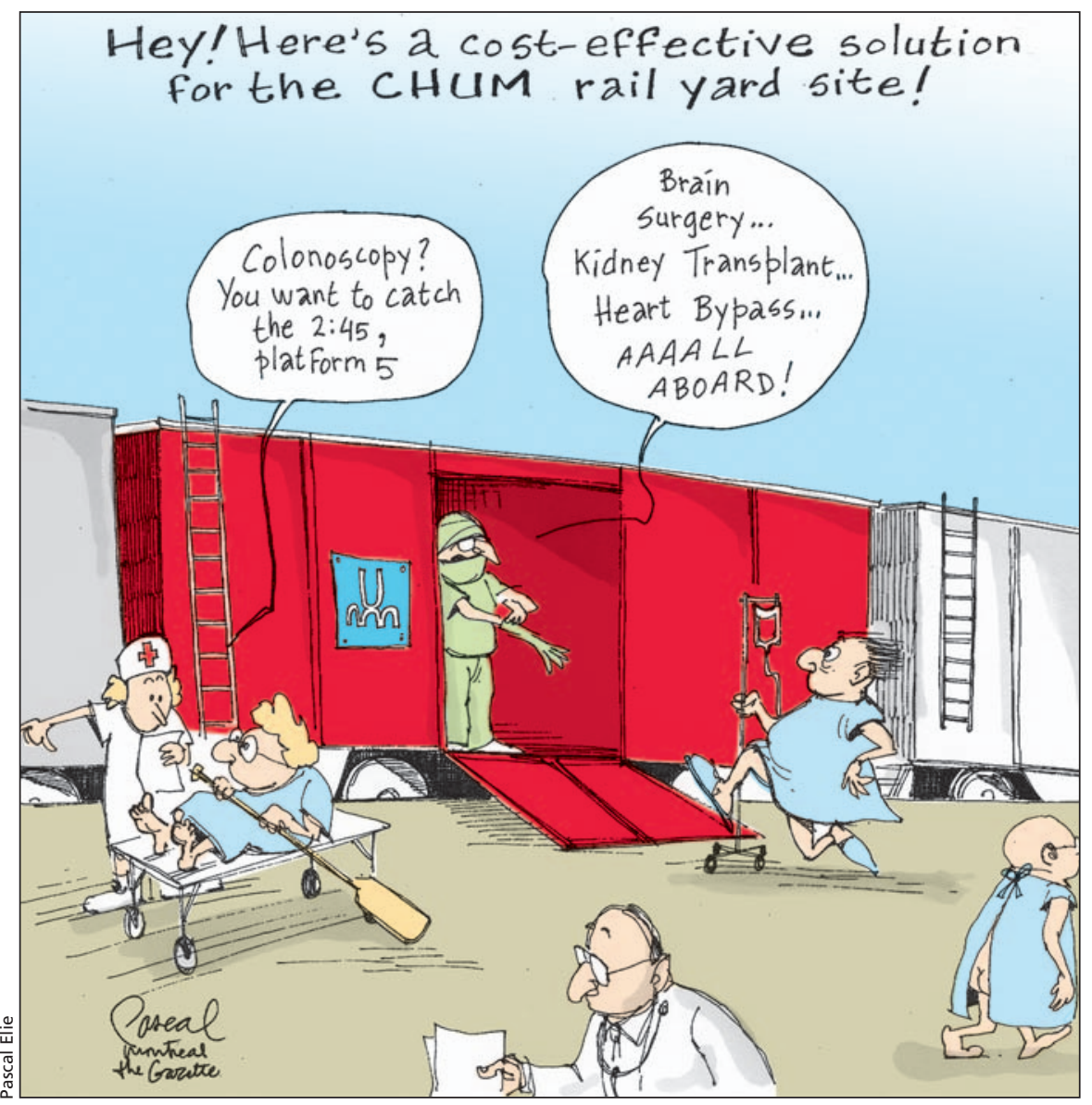

The controversial \$1.5 billion, 700-bed Centre hospitalier de l'Université de Montréal is slated to be built as a public-private partnership hospital next to St. Luc's Hospital in downtown Montréal, Quebec. But the location is a political football, with some favouring a roomier Outrement rail yard site.

monster is unleashed; Foreign Players" (National Post 2008 July 7).

The reference to foreign players stems from the fact that the new approach to financing and building public infrastructure, while relatively new to Canada, has been pioneered in other countries that are now exporting their expertise.

The British Medical Association, which for more than a decade has witnessed the results of the United Kingdom's love affair with P3s (called Private Finance Initiatives over there), has issued dire warnings about the arrangements. "Lots of money has been taken out of the health service" as a result of the way the projects are financed and operated, says
Dr. Jonathan Fielden, chair of the association's consultants' committee.

Private Finance Initiatives have proved to be "a long-term millstone around the neck of the NHS [National Health Service]," Fielden stated in a press release after the September 2008 release of a UK public accounts committee report which concluded that many public sector managers don't have the commercial expertise necessary to oversee the projects over long periods. "Money that was needed for patient care has been diverted from the frontline, and into the hands of private companies," Fielden added.

The Canadian Medical Association, 
meanwhile, has called for guidelines to improve accountability for the use of taxpayers' money. In August 2008, its general council voted to develop "a policy framework and principles" for public-private partnerships in the capitalization, management and delivery of publicly funded health services.

The CMA's background to the motion notes that the UK experience raises several issues including "value for money, transparency, the degree to which they increase service capacity, the impact on the public delivery sector and the sharing of risk."

Because public-private partnerships for hospitals have had a relatively low profile, the CMAJ has produced the following primer on the issue:

\section{What is a "public-private partnership" hospital?}

Several different types of publicprivate partnerships for hospital development exist, all of which involve long-term obligations.

Typically, a consortium, consisting of several private companies that bundle together their services, bids on a hospital project. Consortium partners generally include construction companies, design firms/architects, financiers, property management firms and, sometimes, providers of janitorial, food and other "soft" services. The consortia bid to design, build and finance a hospital, and the deal usually includes a multi-decade contract to maintain the building and, sometimes, to operate those "soft" services.

Traditionally, Canadian hospitals have been built using monies from a government's general revenues or bond issues. By contrast, in public-private partnerships, the consortium finances the project, usually on a long-term basis and the government makes regular payments for those financing costs (sort of like a mortgage payment) and for whatever other services are provided by the consortium. Some projects have been done on a lease back arrangement where the consortia owns the building and leases it to the province - while in others, the hospital board owns the title.

Proponents generally acknowledge that financing costs for the partnership projects are higher than traditional ones, because the public sector has access to cheaper capital. Transaction costs are also higher, because the deals are incredibly complicated. A point of contention is whether these higher costs are, as proponents argue, offset by the "risk transfer" calculations, as a result of which the consortia agrees to absorb risks associated with delays caused by issues such as supplier disruptions or weather problems. Critics, mainly health coalitions and unions, argue that the risk transfer calculations are invariably inflated.

\section{Who is involved?}

International firms, many with experience in British and Australian public-private partnerships, have become key players in Canada. Australia has sometimes been credited with pioneering the public-private partnership approach to public infrastructure, but the United Kingdom became the most enthusiastic proponent.

Names that crop up repeatedly in conjunction with Canadian hospital projects include UK-based John Laing Investments Limited, Innisfree Ltd. and Carillion (with its subsidiary Carillion Canada Inc.), along with Australiabased Babcock \& Brown and Plenary Group. Other international players include German-based Bilfinger Berger and Deutsche Bank.

Consortia usually include large Canadian construction companies - the same ones involved in more traditional projects. The deals are also worked on by management consultant companies, as well as Canadian accounting and legal firms. Among the investors are large Canadian pension funds and international financial institutions.

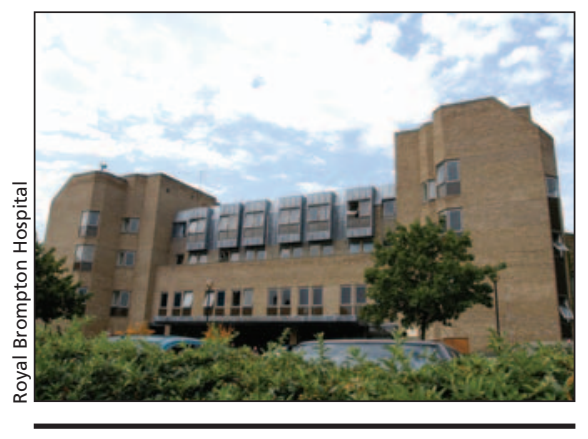

The Royal Brompton Hospital, a London, England, facility that specializes in heart and lung treatment, was part of a public-private partnership "super hospital" initiative that was abandoned after 5 years of planning because of escalating costs.
Meanwhile, Ontario, Quebec and British Columbia have all created government agencies to facilitate publicprivate partnerships:

- Infrastructure Ontario (which refers to the arrangements it makes as Alternative Financing and Procurement (AFP) projects.)

- Partenariats public-privé Québec

- Partnerships BC

Other provinces have not yet jumped on the bandwagon. While Alberta is experimenting with publicprivate partnerships for another key public institution - schools - it has stayed with conventional procurement methods of hospital construction.

\section{Where is it happening?}

Ontario and British Columbia both launched their first public-private partnership hospital projects in 2001.

With 26 hospitals in the works, Ontario currently has the most building activity, while British Columbia has 2 completed hospital projects and 4 others in various stages of development, according to Partnerships BC.

There are 3 proposed projects in Quebec. In addition to the McGill University Health Centre, there is another proposed public-private partnership hospital in Montréal, the Centre hospitalier de l'Université de Montréal, and one in Québec City, the Centre hospitalier universitaire de Québec.

Some of these projects are listed on the website of the Canadian Council for Public-Private Partnerships, an advocacy group with about 200 corporate members as well as many towns, cities and provincial ministries as public members. The council maintains a "PPP Project Tracker" feature.

The first provincial hospitals completed using the public-private partnership model have been highly controversial.

British Columbia's flagship project was the Abbotsford Regional Hospital and Cancer Centre, with an estimated cost of $\$ 1.6$ billion. Planning began in 2001 and it was officially opened in September 2008. When the Fraser Health Authority balked at abandoning traditional procurement methods for the project, on the grounds that the project was not large enough to attract bids from highly experienced firms, the 
province "ordered the board to accept the project as a DBFO [Design, Build, Finance, Operate] P3 or face removal," (Canadian Public Administration 2008;51[1]:71-97). In the end, there was only one bidder, even though the scope of the project, and the costs, had increased substantially.

Ontario's first forays into public-private partnership for hospital construction — the William Osler Health Centre in Brampton and the Royal Ottawa Mental Health Centre - proved similarly controversial. Both projects, announced by the Ontario Conservative government, involve agreements in which the consortium finances, builds, leases and operates the facility, while providing nonclinical services such as food preparation, security and laundry services. In the case of Brampton, the services include patient records.

Reports by the Ontario Health Coalition and the Ontario Public Service Employees Union have detailed numerous problems with the 2 hospitals. In particular, the bifurcated management structure of the hospitals - with the hospital boards and the private consortia having different and sometimes conflicting interests - creates difficulties, the critics note. The projects initiated by Infrastructure Ontario, the agency created by the Ontario Liberal government after the Ottawa and Brampton hospitals had been announced, have scaled back private involvement, somewhat, in subsequent projects. For example, hospital boards retain title of the hospitals, rather than ownership staying with the consortium on a lease back agreement (with the ownership reverting to hospital boards only after several decades).

\section{Why are the provinces embracing public-private partnerships for hospitals?}

Very few people would dispute the need to revitalize much of the public infrastructure in Canada, including hospitals, but the answer to 'why this approach?' as opposed to a more traditional procurement model depends on who you ask.

The rationales cited most often by proponents are the opportunity to capture the expertise of the private sector and the built-in necessity of determining, up front, the scope and cost of the project in order to minimize surprises.

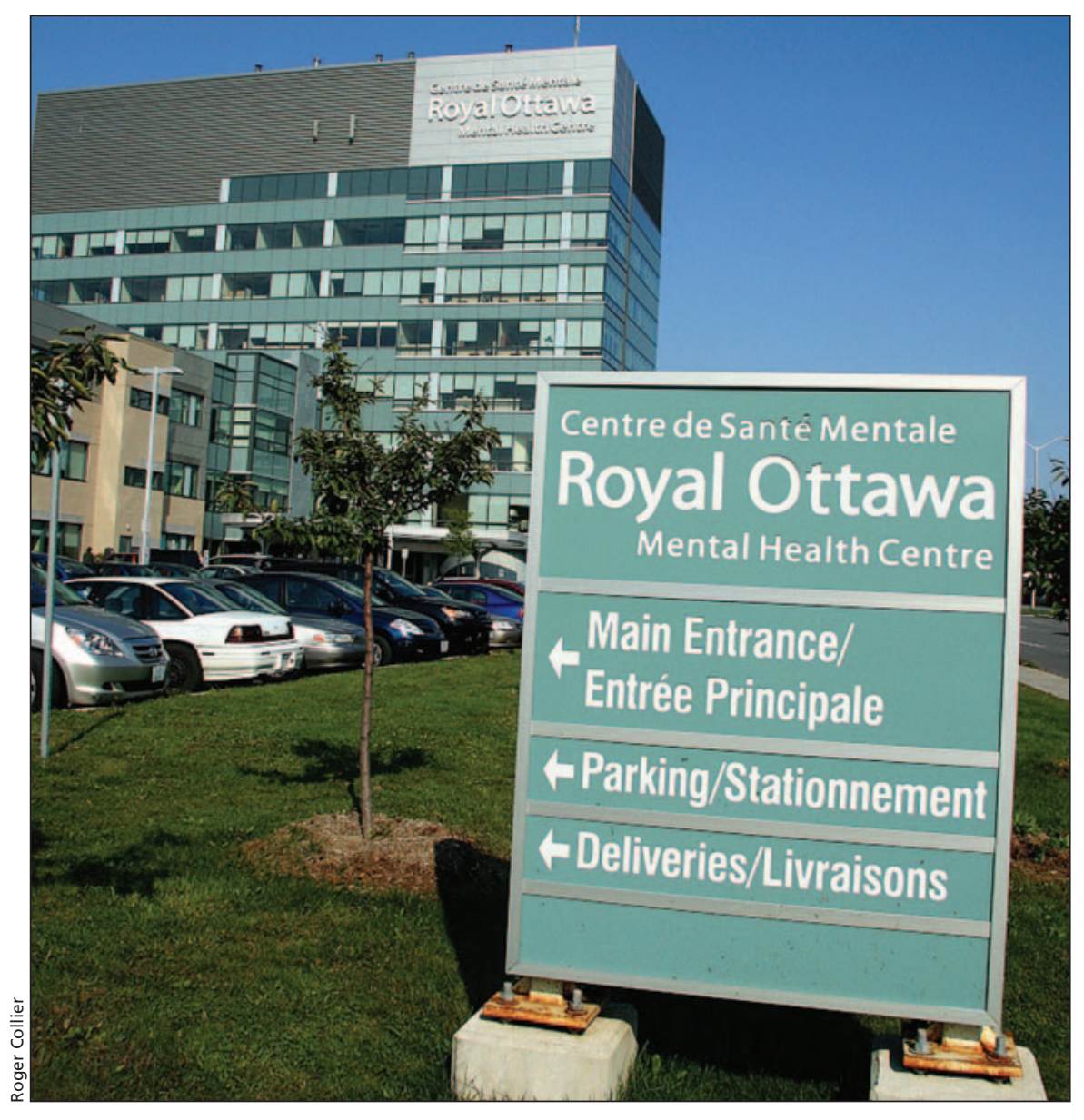

The Royal Ottawa Hospital was one of the first public-private ventures. It is owned by the private partners, who hold long-term maintenance and soft service contracts.

Critics counter that the shift is the product of the ideological notion that the private sector can do things better and a reluctance to bolster public sector expertise in contracting.

What is clear is that public-private partnerships have rapidly, and relatively quietly, become received wisdom within government. In the past 2 budgets, the federal government announced a \$1.2billion fund to encourage public-private partnerships - though none of this money was allocated for health care facilities — and a \$25-million federal office to assist the endeavour. British Columbia explicitly encourages the public sector to consider alternative procurement approaches; Premier Gordon Campbell is an enthusiastic proponent and Partnerships BC champions the approach.

Livingstone says Ontario would never have been able to embark on its ambitious hospital development plans without the advent of public-private partnerships, in large part because project management responsibilities are assumed by the winning consortium. "We leverage private sector expertise to get more done," he says.

But critics of the new approach mostly health coalitions and unions, alongside a few academics - argue that partnerships are set up to make money for the private sector that should go to health care, increasing the overall cost to the public while decreasing control. As well, private companies involved in running hospitals and managing services have a core interest "in expanding the amount of privatization, provided they can make money," says Natalie Mehra, director the Ontario Health Coalition. Ann Silversides, CMAJ

DOI:10.1503/cmaj.081540

Part 1 of a series. Next issue: a polarized debate. 